\title{
Report on the seminar: An investigation of Calvin's principles of Biblical interpretation
}

\author{
B G Armstrong \\ Department of History \\ Georgia State University, U S A
}

\begin{abstract}
This article serves as a report on the seminar on 'Calvin the Preacher', held at the University of Pretoria during the Fifth South-African Congres of Calvin Research. In the seminar, where various examples of Calvin's interpretation were discussed, the basic principles of Calvin's method were enumerated. Although the discussions ranged far and wide, a valuable insight was gained in Calvin's methods. At the same time it became clear that Calvin's principles of Biblical interpretation had to receive more attention.
\end{abstract}

\section{INTRODUCTORY REMARKS TO THE SEMINAR}

It is my purpose this morning to investigate with you some of Calvin's lesser-known, but, if one is attentive in his or her reading, frequently-stated principles of his theology and Biblical exegesis, primarily revealed in his work as preacher, lecturer, and commentator. The selective nature of the texts is evident if I remind you that the corpus of Calvin's writing is enormous, that in each fortnight he preached at least eight sermons, lectured at the 'school' at least six times, and summarized the Bible study of all of the pastors in Geneva and environs at least twice. In addition he would write, on average, forty-one letters, often multi-paged, plus one to two short treatises, and most likely some part of his Institutes, which he constantly revised and enlarged. And this is to say nothing of his direction and admonitions in the Consistory, the records of which are for the first time just now being published, nor of his many remonstrances at the meetings of the Small and Large Councils which formed the political structure and leadership of Geneva, nor of his attendance at various Collequies and Diets in many venues of the European theatre. And we think that we are busy!

Most of the references we use today will be from his Psalms' Commentary, first published in 1557. It is chosen because it is one of only three of his works which can be called a true commentary (the other so-called 'commentaries' were originally sermons or lectures), and because it is perhaps his favorite Biblical book.

It probably goes without saying that the importance of these theological and exegetical principles is evident from the fact that the great majority of his enormous lite- 
rary output is connected with his Biblical exposition. There is not the slightest doubt but that Calvin held a high view of Scripture. This is a commonplace which needs no documentation. Yet it is also important to note that, as well, he affirms the idea of a 'dual authorship' of Scripture, a human one (the historical figures who wrote the text), and divine authorship (the Holy Spirit). The basic and essential role of the Holy Spirit is seen, amongst others, in the text of his Introduction to the Psalms Commentary 'Indeed, here the Holy Spirit has most acutely portrayed all the anquish, sorrow, apprehension, uncertainty, hope, concern, anxiety - in brief, all the unsettling emotions with which the human spirit is customarily troubled'. It can also be seen in his commentary on Ps 44:19: 'The Holy Spirit dictates to us a form of prayer'. And again, on Ps 47:2: 'The design of the Holy Spirit here is to teach ....' Et cetera! (cf Institutes III.21.3: 'For Scripture is the school of the Holy Spirit where just as nothing is omitted which is both necessary and useful to know, just so nothing is taught which is not profitable to know').

At the same time, Calvin is not the least bit reluctant to read the text critically as he seeks to know the mind and intention of the human author. $\mathrm{He}$ is always concerned to be able to say, as he does in his Commentary on Psalm 8, 'By exposing/opening up the mind of the prophet [i e, the human author's], I have now discharged the duty of a faithful interpreter' - which, for him, is to determine the intention of the writer. On the other hand, he feels himself free to regard the words of the human author as the phraseology, predelections and ideas of a sinful, limited human being, even a human being with faulty understanding, as well as recognising that the copyists of the texs may have often been mistaken. In general, though, he believes that the human and divine intention are in accord and he does not countenance an exegesis which tries to pick and choose between an 'uninspired human instrument' and the inspiration of the Holy Spirit. But, he does, of course, forcefully affirm and protect the prerogative to read the text critically.

Other dualities which form one reality in Calvin's teaching (Old- and New Testament $\mathrm{e}$ g) could be cited and developed, and they could be shown to be foundational to his theological and exegetical program, but the task I have envisioned for this seminar is not an exploration of these 'side roads,' but rather to consider together some of the texts which point up the more specific principles which underly his exegesis.

In the texts which I provide, I will not try to determine for you the principle which may be discovered, hoping to sort it out and to see it develop by consensus of the attendees of the seminar. But I recognize, of course, that just the act of selecting and grouping the texts will prejudice the discussion in certain ways. Hopefully these will not be too insidious and determining! 
In order to give coherence to our discussions I ask that you please keep the following three questions in mind as issues to be decided as we seek answers from the texts which are provided as examples of his interpretive program:

* With what problem or issue does Calvin deal in this text?

* What is his conclusion?

* On what type of evidence, or through what process, does he arrive at his conclusion?

\section{EXAMPLES OF CALVIN'S HISTORICAL AND CRITICAL INTERPRETA- TION}

An example of Calvin's historical and critical analysis was given in his commentary on Psalm 9. Here Calvin concludes, after an analysis of the text, that this Psalm was not made directly after the death of Goliath. He points out that the Psalm suggests that the ark is on Mount Zion (vs 11) and this only took place towards the end of David's reign.

The second example was from Psalm 74 where Calvin states: 'It is easy to gather from the context of the Psalm that its composition cannot be ascribed to David, for in his time there was no ground for mourning over such a wasted and calamitous condition of the church ....'

The third example came from Psalm 50:1. Here Calvin asks the question: '... whether the prophet here must be considered as addressing the men of his own age ...' His conclusion is that the prophet '... the whole world as convened ... for the purpose ... of hearing God plead his cause with the Jews in its presence'.

In the discussion it was noted that Calvin's first is the text he has before him which represents the writer's thoughts. He therefore takes care to establish the meaning of the text, as he does in the 'title' of Psalm 9. In the second place it is interesting to note how Calvin, drawing on his knowledge of Biblical history and through logical reasoning and deductions made from the text, takes time to establish the authorship of the specific Psalm, as in the examples from Psalm 9:1 and Psalm 74. At the same time he tries to establish when the Psalms were written. This correlates with Calvin's dictum that the primary duty of the expositor is to lay open the mind of the writer whom he has undertaken to explain. Therefore the identity of the writer and the historical setting of the text are of importance for the explanation thereof. 


\section{THE TEXTS OF THE EXAMPLES}

\subsection{The title of Psalm 9}

'This title is variously explained. Some translate it 'Upon the death of Laben', and their opinion is, that he was one of the chief captains of his [David's] enemies. Others think it to be rather some feigned name, and are of opinion, that Goliath is meant in this Psalm; while others believe that it was an instrument of music. But as for me it seems more correct, or at least, as in an obscure matter, more likely, that it was the beginning of some well-known ballad, to the tune whereof this Psalm was set. And whereas the interpreters make a question what victory it could be that David sets out here, in my judgment this is absurd.

First, as to their opinion, that it is a song of victory, wherein David simply yields thanks unto God, the very context refutes their error. For although the greater part is employed in singing the praises of God, yet must it all be referred unto praying. That he may raise up his mind to trust in God, he, as is his wont, calls to mind by what signal display of God's power he had heretofore been delivered from the violence and the hand of his enemies. Thus it is a mistake to restrain to one victory this thanksgiving, in which he intends to include many deliverances.

... And this confirms what I have said already: namely, that this Psalm was not made after the death of Golliath, because that by God's commandment the ark of the covenant was not removed into Sion until a little before the end of David's reign. For harsh and forced is the conjecture of some, that David, by the spirit of prophecy, spoke of it as of a thing to come'.

Can Calvin's argument here be sustained that by historical chronology one must conclude that David did not compose Psalm 9 at the time of his victory over Goliath since the ark being on Mount Zion is mentioned, which was a much later event? What might this mean for other historically-pregnant passages?

\subsection{The introduction to Psalm 74}

Psalm 74, The introduction: 'It is easy to gather from the contents of the psalm, that its composition cannot be ascribed to David; for in his time there was no ground for mourning over such a wasted and calamitous condition of the Church as is here depicted. Those who are of a different opinion allege, that David by the spirit of prophecy foretold what had not yet come to pass. But, as it is probable that there are many of the psalms which were composed by different authors after the death of David, this 
psalm, I have no doubt is not one of their number. What calamity is here spoken of, it is not easy precisely to determine ... the conjecture will be more probable that these complaints belong to the time of Antiochus [Epiphanes] ....

Conclusions for this text based on the questions posed above?

\subsection{Psalm 50:1}

'The opinion has been very generally entertained, that the psalm points to the period of the Church's renovation, and that the design of the prophet is to apprise the Jews of the coming abrogation of their figurative worship under the law. ... the ... question is, whether the prophet here must be considered as addressing the men of his own age, and simply condemning the abuse and corruption of the legal worship, or as predicting the future kingdom of Christ? ... the answer is obvious, that the prophet in this place describes the whole world as convened not for the purpose of receiving one common system of faith, but of hearing God plead his cause with the Jews in its presence'. Again using the above-posed questions, what are your conclusions?

\subsection{Psalm 75:3}

$\therefore \ldots$ of the second part of the verse, I will establish the pillars of it, they [many commentators] make the same application, explaining it as if Christ had said, As soon as I come into the world, the earth with its inhabitants shall melt and be dissolved; but immediately thereafter I will establish it upon firm and solid foundations; for my elect ones, renewed by my Spirit, shall no longer be like grass or withered flowers, but shall have conferred upon them new and unwonted stability. I do not think, however, that such a refined interpretation ever entered into the mind of the prophet, whose words I consider as simply meaning, that although the earth may be dissolved, God has the props or supports of it in his own hand'.

\section{EXAMPLES OF CALVIN'S HISTORICAL, ETYMOLOGICAL, CON- TEXTUAL AND COMPARATIVE INTERPRETATION.}

Although the discussions on the next set of examples cannot be discussed in extenso, a few remarks can be made. In the discussion of Psalm 55:22 and Psalm 59:10 it became evident that Calvin insists on staying with the Biblical text he has before him. As he puts it: '.. we must be ever on our gaurd against wresting Scripture from its natural meaning'. Calvin rejects and translations and explications which do not give the original text, as it is given, it's full weight. 
At the same time it also becomes clear that Calvin has a good command of the Hebrew language. In his explanation of Psalm 71:16 he rejects Augustin's explanation and says Augustin '.. puts a sense upon them (ie the Hebrew words) foreign to the genuine meaning'. He also rejects an allegorical explanation of Psalm 19:4 stating that the literal meaning, carefully considered, is of more value for understanding the text than the allegorical.

In the wide ranging discussion of these examples of Calvin's exegesis and commentary it was noted that Calvin was a very carefull reader of the Bible and that he respected the text. In this way Calvin's exegesis has an etymological accent as he tries to correctly understand every word so that he can expound the thoughts of the psalmist in a precise manner. Through his knowledge of Scripture Calvin often relies on a comparative exegesis to explain the intention of the text.

\section{THE TEXTS OF THE EXAMPLES}

\subsection{Psalm 16:9}

'Therefore my heart is glad'. In this verse he commends the incomparable fruit of faith, whereof the scripture makes mention everywhere; namely, that we live under God's protection, not only quietly but joyfully and cheerfully. We know that the chief essential of a happy life is tranquillity of mind; as nothing is more miserable than to be tossed amidst sundry cares and alarms. But how much soever the ungodly besot themselves with the spirit of phrensy of lethargy, yet they never enjoy true mirth nor calm quiet of mind; but rather feel tumultuous emotions within themselves, which torment them from time to time, and force them to shake off their drowsiness'.

\subsection{Psalm 16:10}

'... with good reason Peter gathers that David could not have boasted in this way but by the spirit of prophecy, and unless he had an eye to the author of life who was promised to him, who only was to be honoured with this prerogative' ([Ac 2:30). Nevertheless this did not prevent David from lawfully assuring himself of exemption from death, because Christ by His rising again purchased immortality, not for Himself individually, but for us all in general.

I confess that the ancient interpreters, as well Greek as Latin, have drawn these words to an opposite sense; namely, that Christ's soul was brought again from hell: but it is better to continue in their natural simplicity, lest we become a laughingstock to the Jews; and further, lest one subtilty engendering many other, should drive us into a 
labyrinth. Certainly, in the second member, there is without doubt mention made of the body, and we know that nothing is more rife with David than to repeat one thing twice. And although we translate the word nepesh, into Latin, anima, that is to say, Soul; yet among the Hebrews it signifies nothing else but the breath of life, or the life itself'.

What is to be made of the argument that a Christological application does violence to the words of the text (Cf Is 28:10).

\subsection{Psalm 55:22}

The Hebrew term yahab signifies 'to give', and yehabcha, according to the ordinary rules of grammar, should be translated 'your giving', or 'your gift'. Most interpreters, however, have translated it 'your burden,' but they can give no reason for their view. There is absolutely no precedent for supposing that the word might be translated 'burden' (Cast your 'burden' upon YHWH'). They have evidently feit themselves compelled to invent that meaning from the harshness and apparent absurdity of the stricter translation, 'Cast your gift upon YHWH'.

\subsection{Psalm 59:10}

'The God of my mercy will prevent me ....' In the Hebrew, there is the affix of the third person, but we have the point which denotes the first. The Septuagint has adopted the third person, and Augustine too ingeniously, though with a good design, has repeatedly quoted the passage against the Pelagians, in proof that the grace of God is antecedent to all human merit. In the same manner he has again and again cited the preceding verse, to refute the arrogance of those who boast of the power of freewill .... The sentiment inculcated is also, without all doubt, a point and instructive one; but we must be ever on our guard against wresting Scripture from its natural meaning'.

\subsection{Psalm 71:16}

'I will go in the strength of the Lord Jehovah!' '... Augustine quotes this text more than one hundred times as an argument to overthrow the merit of works, and plausibly opposes the righteousness which God gratuitously bestows to the meritorious righteousness of men. It must, however, be confessed that he wrests (twists, distorts) the words of David, and puts a sense upon them foreign to the genuine meaning, which simply is, that he does not rely on his own wisdom, nor upon his own abilities, nor upon his own strength, nor upon his riches, ... but that the only basis (for a sure hope of salvation) is that, since God is righteous, it is not possible that God will forsake him ... his faithfulness in keeping his promises. 
Note Calvin's sobriety in interpreting the text, and his concern to afirm the promises of God and His faithfulness in keeping them. What conclusion is to be drawn from a consideration of the questions posed?

\subsection{Psalm 72}

Intro; 'Those who would interpret it (the psalm) simply as a prophecy of the kingdom of Christ, seem to put a construction upon the words which does violence to them; and then we must always beware of giving the Jews occasion of making an outcry, as if it were our purpose, sophistically, to apply to Christ those things which do not directly refer to him ....'

\subsection{Psalm 19:4}

'Hitherto I have set forth the native meaning of the prophet; for whereas this part of the Psalm has been wrested to allegories, the readers will easily perceive that there was no reason why it should be so. I told you at first, and it also appears from the context, that before David comes to the law, he sets forth God's glory to be beheld in the workmanship of the world. Now, if of the heavens we make the apostles, and of the sun, Christ, that partition can have place no more. Besides, it were the wrong order to place the Law after the Gospel in the text. But as nothing is more clear, than that he treats here of the knowledge of God, which is naturally offered to all men in the mirror of the word, I cease from longer discourse of that matter.

Only, because these allegorical interpreters have taken occasion from the words of Paul, this knot must be untwisted. Paul, discoursing upon the calling of the Gentiles, takes this for a principle, that Whosoever calls upon the name of the Lord shall be saved, and aterwards adds, that $\mathrm{He}$ cannot be called upon until $\mathrm{He}$ be known by the teaching of the gospel. How be it, as the Jews esteemed it as savouring of a kind of sacrilege, that Paul published the promise of salvation to the Gentiles, he demands, whether they also had not heard? And he answers, that out of this place there was open to them a school, wherein they might learn religion and the service of God, because the writing of them went forth into all the earth, \& c. Surely, Paul would then, absurdly in point of time, have said that the Gospel had been heard through the whole world by the mouth of the apostles, when it had scarcely yet come to a few. Verily, their preaching had not then passed into far countries, but abode yet inclosed within the bounds of Jewry. Moreover, his drift is not at all doubtfull; for he meant to say, that God, many hundred years past, had disclosed His glory to the Gentiles, and that the same was as a prelude to a wider doctrine. For although the state of His chosen people were seperate for a time from the heathen, yet it ought not seem strange, that God at length has disclosed Himself indescriminately to them both, whom $\mathrm{He}$ had heretofore 
allured in common unto Him: according as he says in another place, that at what time God suffered the heathen to wander after their own ways, yet He had not left Himself without witness (Acts 14:16-17). Whence we gather, that they were too grossly deceived, who surmised that Paul departed from the literal sense, which the readers shall yet further understand by my commentaries upon that place'.

\subsection{Psalm 35:2}

'Some suppose that the Hebrew word, tsinah, here used means a dart, or some other type of weapon, but as we have seen previously in Psalm 5, it more properly means buckler'.

\section{SOME CONCLUDING REMARKS}

On the whole the seminar discussions demonstrated that most South African researchers are concentrating their attention on Calvin's systematic work and that the sermons and commentaries does not receive the same attention. This introduction to Calvin's interpretation of the Bible and the principles he follows was of significant value. In looking at the various issues that were brought forward in these examples of Calvin's expositions, it became clear that Calvin studied the text very carefully, being allways aware that the word of God can only be understood if the text of the particular Biblical passage is explained in such a way that the full meaning, as intended by the writer, is brought forward.

The following principles of Calvin's interpretation of the Bible were noted. It must be said that not all the questions discussed are mentioned here. In giving this rather expanded seminar report, it is hoped that some insight in the seminar discussions can be gained and the whole question of Calvin's Biblical interpretation will receive more attention. The seminar discussions came to the following answers:

Calvin reads the Biblical text critically because in his explanation of the text the sensus literalis is his first concern. Calvin, in opposition to the scholastic interpreters who searched for a fourfold meaning in the text, was primarily interested in the sensus literalis, as seen in the example of Psalm 55:22. Calvin did however emphasize that the Spirit must never be isolated from the Word and he therefore also found a sensus spiritualis in the written word, for the written word is the speech of the Spirit, as in the example of Psalm 71:16. The sensus spiritualis can however only be understood through the inward illumination of the Spirit. 
In the given examples Calvin states a problem and arrives at a conclusion by taking all the evidence in the text into consideration and then, drawing on his knowledge of Biblical history, correlates this with his understanding of God and his works. He therefore shuns an allegorical explanation to solve the problem although he does allow allegories if they do not proceed beyond the point where they leave the rule of Scripture guiding them.

Calvin's explanations of the texts are sober because he does not want to do more than to explain the meaning of the text. He continually states that the interpreter must stay with the text. 